\title{
Modeling of Gap Closure in Uranium- Zirconium Alloy Metal Fuel - A Test Problem
}

\section{October 2009}

\section{Prepared by}

Balasubramaniam Radhakrishnan

Computer Science and Mathematics Division 


\title{
DOCUMENT AVAILABILITY
}

Reports produced after January 1, 1996, are generally available free via the U.S. Department of Energy (DOE) Information Bridge.

Web site http://www.osti.gov/bridge

Reports produced before January 1, 1996, may be purchased by members of the public from the following source.

\author{
National Technical Information Service \\ 5285 Port Royal Road \\ Springfield, VA 22161 \\ Telephone 703-605-6000 (1-800-553-6847) \\ TDD 703-487-4639 \\ Fax 703-605-6900 \\ E-mail info@ntis.gov \\ Web site http://www.ntis.gov/support/ordernowabout.htm
}

Reports are available to DOE employees, DOE contractors, Energy Technology Data Exchange (ETDE) representatives, and International Nuclear Information System (INIS) representatives from the following source.

Office of Scientific and Technical Information

P.O. Box 62

Oak Ridge, TN 37831

Telephone 865-576-8401

Fax 865-576-5728

E-mail reports@osti.gov

Web site http://www.osti.gov/contact.html

This report was prepared as an account of work sponsored by an agency of the United States Government. Neither the United States Government nor any agency thereof, nor any of their employees, makes any warranty, express or implied, or assumes any legal liability or responsibility for the accuracy, completeness, or usefulness of any information, apparatus, product, or process disclosed, or represents that its use would not infringe privately owned rights. Reference herein to any specific commercial product, process, or service by trade name, trademark, manufacturer, or otherwise, does not necessarily constitute or imply its endorsement, recommendation, or favoring by the United States Government or any agency thereof. The views and opinions of authors expressed herein do not necessarily state or reflect those of the United States Government or any agency thereof. 
DOE Office of Nuclear Energy, Advanced Fuel Cycle Initiative

\section{MODELING OF GAP CLOSURE IN URANIUM-ZIRCONIUM ALLOY METAL FUEL - A TEST PROBLEM}

Date Published: October 2009

S. Simunovic

L.J. Ott

S.B. Gorti

P.K. Nukala

B. Radhakrishnan

J.A. Turner

Prepared by

OAK RIDGE NATIONAL LABORATORY

Oak Ridge, Tennessee 37831-6283

managed by

UT-BATTELLE, LLC

for the

U.S. DEPARTMENT OF ENERGY

under contract DE-AC05-00OR22725 



\section{CONTENTS}

\section{Page}

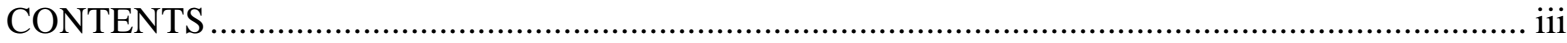

abstract ton.

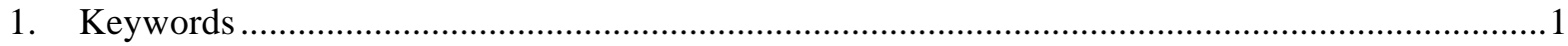

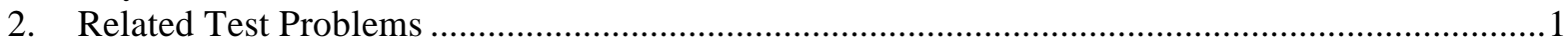

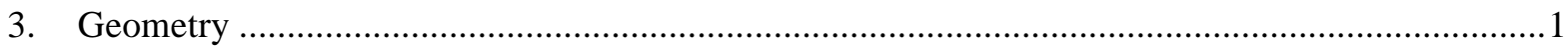

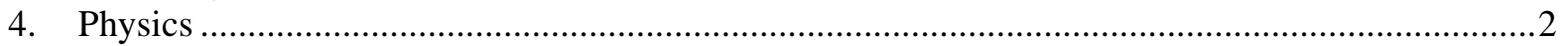

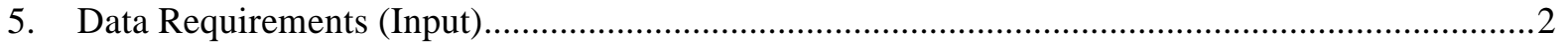

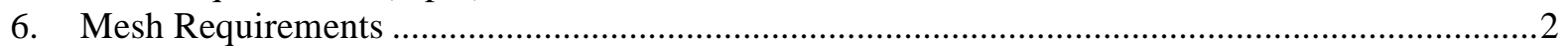

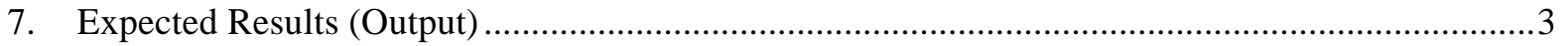

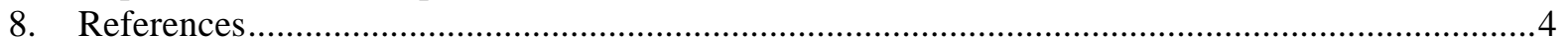

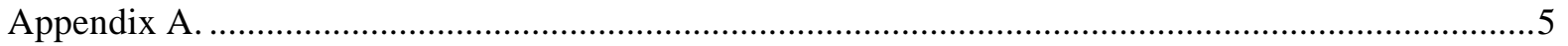

MATERIAL PROPERTIES AND OPERATING PARAMETERS ….........................................

Appendix A. MATERIAL PROPERTIES AND OPERATING PARAMETERS …......................... 7

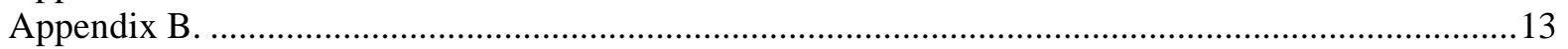

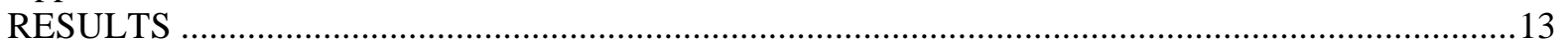

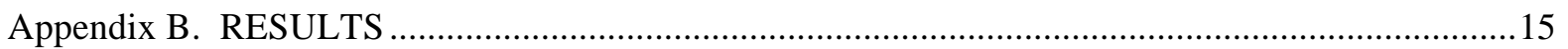





\begin{abstract}
Uranium based binary and ternary alloy fuel is a possible candidate for advanced fast spectrum reactors with long refueling intervals and reduced liner heat rating [1]. An important metal fuel issue that can impact the fuel performance is the fuel-cladding gap closure, and fuel axial growth. The dimensional change in the fuel during irradiation is due to a superposition of the thermal expansion of the fuel due to heating, volumetric changes due to possible phase transformations that occur during heating and the swelling due to fission gas retention. The volumetric changes due to phase transformation depend both on the thermodynamics of the alloy system and the kinetics of phase change reactions that occur at the operating temperature. The nucleation and growth of fission gas bubbles that contributes to fuel swelling is also influenced by the local fuel chemistry and the microstructure. Once the fuel expands and contacts the clad, expansion in the radial direction is constrained by the clad, and the overall deformation of the fuel clad assembly depends upon the dynamics of the contact problem. The neutronics portion of the problem is also inherently coupled with microstructural evolution in terms of constituent redistribution and phase transformation. Because of the complex nature of the problem, a series of test problems have been defined with increasing complexity with the objective of capturing the fuel-clad interaction in complex fuels subjected to a wide range of irradiation and temperature conditions. The abstract, if short, is inserted here before the introduction section. If the abstract is long, it should be inserted with the front material and page numbered as such, then this page would begin with the introduction section.
\end{abstract}

\title{
1. KEYWORDS
}

Fuel swelling, thermo-mechanics, power factor, finite element method, gap closure, fuel clad mechanical interaction (FCMI).

\section{RELATED TEST PROBLEMS}

None.

\section{GEOMETRY}

The metal fuel is in the form of cylindrical slugs, $0.521 \mathrm{~cm}$ in radius and roughly $25 \mathrm{~cm}$ long that are stacked vertically to form a total length of $250 \mathrm{~cm}$. The fuel clad is alloy HT-9 and the initial gap between fuel and clad is $0.069 \mathrm{~cm}$. The fuel pin has an outer diameter of $0.7 \mathrm{~cm}$, with a clad layer thickness of $0.11 \mathrm{~cm}$. The details of the fuel geometry and axial power factors are shown in Table 1 in 
the appendix. The bottom of the fuel is constrained and the slugs are free to expand along the axis and along the radius until the fuel-clad gap closure occurs. The gap between the fuel slugs and the clad is filled with liquid sodium that can be squeezed into the plenum when the fuel expands in the radial direction. The clad is cooled using liquid, flowing sodium with an inlet temperature of $355 \mathrm{C}$. The calculated coolant temperatures and heat transfer coefficients at various axial locations shown in Figures 1 and 2 in Appendix 1 will be used in the finite element calculations.

\section{PHYSICS}

The objective of the test problem is to compute the axial and radial expansion of the fuel given the power density in the fuel elements, the burn-up and the total operating time, so that the time at which the fuel-clad gap closes at various axial positions can be predicted. The physics tested includes heat transfer in the presence of internal heat sources in the fuel, coupled thermo-mechanical and fission gas induced strain in the fuel and clad, and fuel-clad contact dynamics. The initial conditions include the coolant temperature, power density distribution, and burn-up distribution within the fuel slugs. Boundary conditions include constraint of axial displacement along the bottom surface with full constraint for the central node on the bottom surface while all other external surfaces are constraintfree. When fuel expands radially and contacts the clad, sticking friction between the two surfaces is assumed. This is the simplest version of the suite of problems with the following assumptions: Isotropic volume expansion, expansion due to swelling superimposed on thermal expansion without consideration of stress redistribution, isotropic constitutive response for fuel and clad, constant coolant temperature, no phase change in fuel. The fuel modeled is $\mathrm{U}-10 \% \mathrm{Zr}$. The constituent redistribution is

neglected and the neutronics is specified simply through power factors that remain constant throughout the run at a given axial position.

\section{DATA REQUIREMENTS (INPUT)}

Initial geometry, material properties (thermal expansion coefficient, elastic moduli, Poisson's ratio, heat capacity, density, thermal conductivity) and irradiation parameters including axial power factors and peak burnup. The material properties and process parameters are listed in Appendix 1.

\section{MESH REQUIREMENTS}

Tetrahedral and brick elements. 


\section{EXPECTED RESULTS (OUTPUT)}

1. Radial and axial temperature distribution in the fuel elements

2. Fuel-clad gap closure as a function of operation time

3. Fuel axial growth as a function of operation time

The results will be compared against data for U-10\% Zr fuel computed by Kim et al [1]. Results will also be compared with those obtained using the commercial finite element code ABAQUS, which can be used to perform thermal and mechanical analysis (including contact). The analysis using ABAQUS will be performed by assuming a 2-D axi-symmetric geometry for the fuel pin, and will require specification of the fuel swelling through a user-defined subroutine that is typically used to prescribe thermal expansion. Unlike the results of Kim et al. [1], which were computed by considering the fuel to be made of 10 sections in the axial direction that behave independently, the ABAQUS model will consider the entire fuel geometry as a single unit, and will therefore provide a more realistic basis for comparison with the 3-D model. In addition, different contact conditions ranging from sliding to sticking friction can be modeled, and will be used to assess the effect of different friction values on the axial growth of the fuel rod. The results obtained to-date are shown in Appendix 2. 


\section{REFERENCES}

1. Y. S. Kim, A.M. Yacout, G.L. Hofman and H.J. Ryu, "U-Zr Constituent Redistribution, Gap Closure and Axial Growth in Reduced-Power Fast Reactor Fuel Designs," ANL Report?

2. Y.S. Touloukian, "Thermophysical Properties of Matter"

3. Y. Takahashi, M. Yamawaki, and K. Yamamoto, "Thermophysical Properties of Uranium-Zirconium Alloys," JNM, 154, 1988, 141-144

4. Y. Takahashi, K. Yamamoto, et al, "Heat Capacities of Uranium-Zirconium Alloys from 300 to $1100 \mathrm{~K}$," JNM, 167, 1989, 147-151

5. M. Hansen,"Constitution of Binary Alloys"

6. "SCDAP/RELAP5/MOD3.2 Code Manual Volume IV : MATPRO - A Library of Materials properties for LWR Accident Analysis," NUREG/CR-6150, October 1997

7. Kirk-Othmer Encyclopedia of Chemical Technology

8. Bauer, "An Evaluation of the Properties and Behavior of Zirconium-Uranium Alloys," BMI-1350, 1959. 
APPENDIX A.

MATERIAL PROPERTIES AND OPERATING PARAMETERS 

Table 1: Fuel geometry and design parameters (from Kim et al. [1])

\begin{tabular}{|c|c|c|c|c|c|}
\hline & \multicolumn{2}{|c|}{ U-10Zr / HT-9 } \\
\hline \multicolumn{4}{|c|}{$\mathrm{U}-235$ enrichment $(\%)$} & & 19 \\
\hline \multicolumn{4}{|c|}{ Fuel length (L), cm } & & 250 \\
\hline \multicolumn{4}{|c|}{ Fuel density, $\mathrm{g} / \mathrm{cm}^{3}$} & & 15.67 \\
\hline \multicolumn{4}{|c|}{ Fuel slug radius, $\mathrm{cm}$} & & 0.521 \\
\hline \multicolumn{4}{|c|}{ Radial fuel-cladding gap, cm } & & 0.069 \\
\hline \multirow{2}{*}{\multicolumn{4}{|c|}{$\begin{array}{l}\text { Fuel planar smeared density, \% } \\
\text { Average linear power, W/cm }\end{array}$}} & & 78 \\
\hline & & & & & 39 \\
\hline \multicolumn{4}{|c|}{ Coolant inlet temperature, ${ }^{\circ} \mathrm{C}$} & & 355 \\
\hline \multicolumn{4}{|c|}{ Peak clad inner temperature, ${ }^{\circ} \mathrm{C}$} & & 609 \\
\hline \multicolumn{4}{|c|}{ Predicted peak burnup (at\%) } & & 5 \\
\hline \multirow[b]{2}{*}{$\begin{array}{l}\text { Axial location } \\
\text { from bottom } \\
(\mathrm{z} / \mathrm{L})\end{array}$} & \multicolumn{4}{|c|}{ Case 1} & Case 2 \\
\hline & $\begin{array}{l}\text { Step } \\
1 \\
0 \\
6.3 \\
\text { (year) }\end{array}$ & $\begin{array}{l}\text { Step } 2 \\
6.3- \\
22 \\
\text { (year) }\end{array}$ & $\begin{array}{l}\text { Step } 3 \\
22- \\
\text { (year) }\end{array}$ & 30 & $0-30$ (year) \\
\hline $0.056($ node 1$)$ & 1.01 & 0.63 & 0.52 & & 0.59 \\
\hline 0.17 (node 2$)$ & 1.61 & 0.99 & 0.81 & & 0.98 \\
\hline $0.28($ node 3$)$ & 1.65 & 1.25 & 1.04 & & 1.23 \\
\hline $0.39($ node 4$)$ & 1.43 & 1.41 & 1.19 & & 1.33 \\
\hline $0.50($ node 5$)$ & 1.11 & 1.44 & 1.29 & & 1.34 \\
\hline $0.61($ node 6$)$ & 0.88 & 1.31 & 1.32 & & 1.23 \\
\hline 0.72 (node 7$)$ & 0.68 & 1.02 & 1.24 & & 1.07 \\
\hline 0.83 (node 8$)$ & 0.48 & 0.62 & 1.00 & & 0.81 \\
\hline $0.94($ node 9$)$ & 0.28 & 0.31 & 0.58 & & 0.46 \\
\hline
\end{tabular}


Coolant fluid temperature as a function of core height

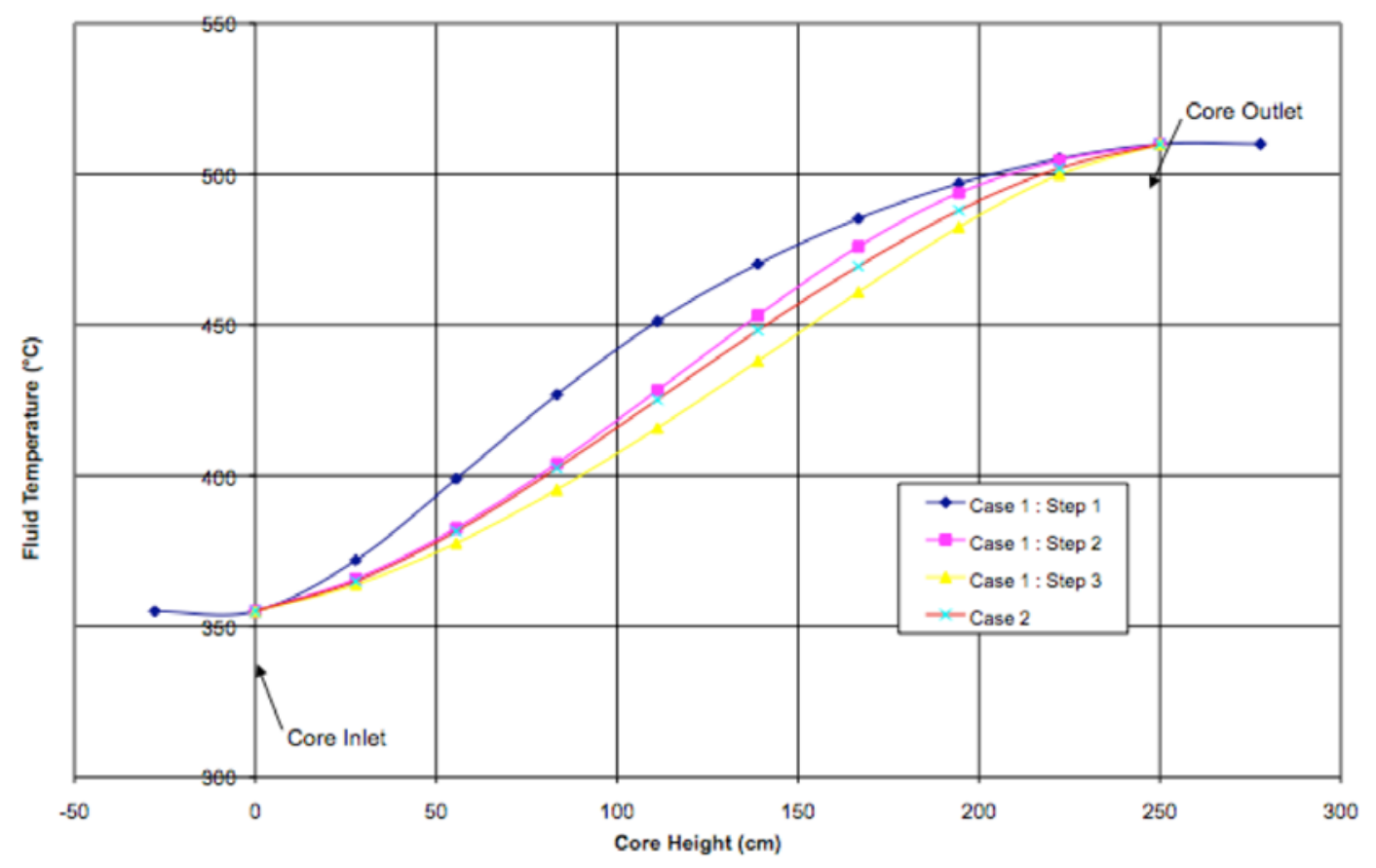

Surface heat transfer coefficient as a function of core height

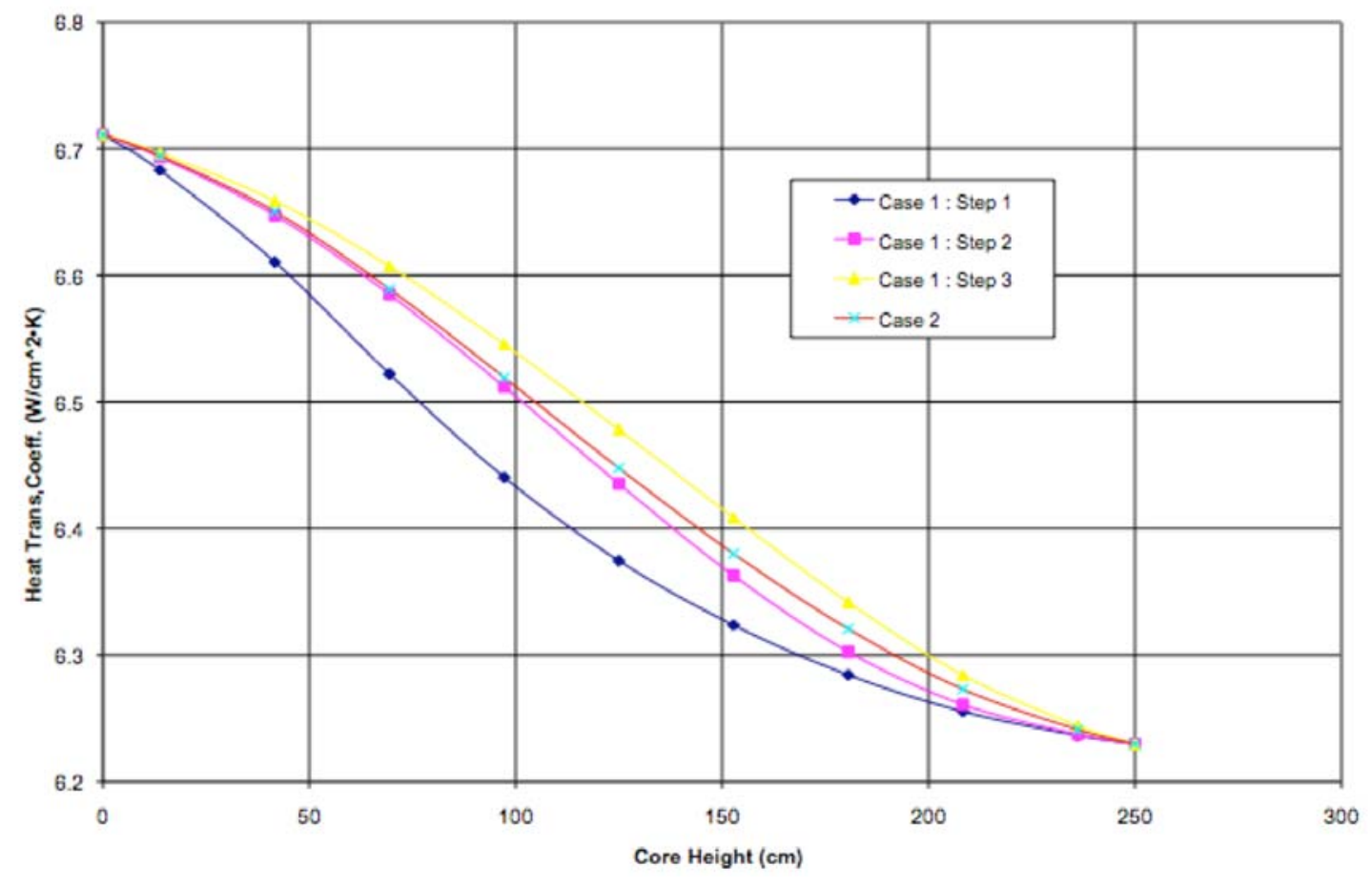

Table 2. Renormalization of peaking factors from Table 1 
Case 1 : Step 1

\begin{tabular}{|c|c|c|c|}
\hline & Node & $\begin{array}{l}\text { Original } \\
\text { Peaking } \\
\text { Factors }\end{array}$ & $\begin{array}{c}\text { Renormalized } \\
\text { Peaking } \\
\text { Factors }\end{array}$ \\
\hline \multirow[t]{8}{*}{ bottom } & 1 & 1.01 & 0.995618839 \\
\hline & 2 & 1.61 & 1.587075575 \\
\hline & 3 & 1.65 & 1.626506024 \\
\hline & 4 & 1.43 & 1.409638554 \\
\hline & 5 & 1.11 & 1.094194962 \\
\hline & 6 & 0.88 & 0.86746988 \\
\hline & 7 & 0.68 & 0.670317634 \\
\hline & 8 & 0.48 & 0.473165389 \\
\hline \multirow[t]{2}{*}{ top } & 9 & 0.28 & 0.276013143 \\
\hline & $\begin{array}{l}\text { Sum } \\
(1: 9)\end{array}$ & 9.13 & 9 \\
\hline $\begin{array}{l}\text { Revis.fa } \\
\text { sum } / 9\end{array}$ & & 1.014444444 & 1 \\
\hline
\end{tabular}

Case 1 : Step 2

Case 1 : Step 3

$\begin{array}{cr}\begin{array}{c}\text { Original } \\ \text { Peaking } \\ \text { Factors }\end{array} & \begin{array}{c}\text { Renormalized } \\ \text { Peaking } \\ \text { Factors }\end{array} \\ & \\ 0.63 & 0.631403118 \\ 0.99 & 0.9922049 \\ 1.25 & 1.252783964 \\ 1.41 & 1.413140312 \\ 1.44 & 1.443207127 \\ 1.31 & 1.312917595 \\ 1.02 & 1.022271715 \\ 0.62 & 0.621380846 \\ 0.31 & 0.310690423 \\ & \\ 8.98 & 9 \\ 0.997777778 & 1\end{array}$

$\begin{array}{cr}\begin{array}{c}\text { Original } \\ \text { Peaking } \\ \text { Factors }\end{array} & \begin{array}{c}\text { Renormalized } \\ \text { Peaking } \\ \text { Factors }\end{array} \\ & \\ 0.52 & 0.52057842 \\ 0.81 & 0.810901001 \\ 1.04 & 1.041156841 \\ 1.19 & 1.191323693 \\ 1.29 & 1.291434928 \\ 1.32 & 1.321468298 \\ 1.24 & 1.24137931 \\ 1 & 1.001112347 \\ 0.58 & 0.580645161 \\ & \\ 8.99 & 9 \\ 0.998888889 & 1\end{array}$




\section{Case 2}

$\begin{array}{ccc} & \text { Original } & \text { Renormalized } \\ & \text { Peaking } & \text { Peaking } \\ \text { Node } & \text { Factors } & \text { Factors }\end{array}$

$\begin{array}{llll}\text { bottom } & 1 & 0.59 & 0.587389381 \\ & 2 & 0.98 & 0.975663717 \\ & 3 & 1.23 & 1.224557522 \\ & 4 & 1.33 & 1.324115044 \\ & 5 & 1.34 & 1.334070796 \\ & 6 & 1.23 & 1.224557522 \\ & 7 & 1.07 & 1.065265487 \\ & 8 & 0.81 & 0.806415929 \\ \text { top } & 9 & 0.46 & 0.457964602\end{array}$

$\begin{array}{ccc}\text { Sum } & & \\ (1: 9) & 9.04 & 9 \\ \text { Revis.factor }=\text { sum } / 9 & 1.004444444 & 1\end{array}$

\section{U-10Zr Thermophysical properties}

\section{Density:}

$$
\begin{aligned}
& \rho(\mathrm{T})=15.67 *\left(1.0-3^{*} \Delta \mathrm{L}(\mathrm{T}) / \mathrm{L} 300\right) \\
& \text { where: } \rho[=] \mathrm{gm} / \mathrm{cm}^{3}
\end{aligned}
$$

$$
\mathrm{T}[=] \mathrm{K}
$$

$\begin{array}{ccc}\begin{array}{c}\text { Temperature } \\ (\mathrm{K})\end{array} & \begin{array}{c}\text { Theoretical } \\ \text { Density } \\ \left(\mathrm{gm} / \mathrm{cm}^{3}\right)\end{array} & \Delta \mathrm{L}(\mathrm{T}) / \mathrm{L} 293 \\ 293 & 15.670 & 0 \\ 300 & 15.666 & 0.000088 \\ 400 & 15.603 & 0.001422 \\ 500 & 15.538 & 0.002814 \\ 600 & 15.466 & 0.004329 \\ 700 & 15.386 & 0.006036 \\ 800 & 15.294 & 0.008000 \\ 900 & 15.186 & 0.010289\end{array}$




\section{Thermal Conductivity:}

\begin{tabular}{|c|c|}
\hline & $\begin{array}{l}\mathrm{k}(\mathrm{T})=0.09620358+0.000224774 * \mathrm{~T}+3.26631 \mathrm{e}-08 * \mathrm{~T} * \mathrm{~T} \\
\text { where: } \mathrm{k}[=] \mathrm{W} / \mathrm{cm} * \mathrm{~K} \\
\quad \mathrm{~T}[=] \mathrm{K}\end{array}$ \\
\hline $\begin{array}{l}\text { Temperature } \\
(\mathrm{K})\end{array}$ & $\begin{array}{l}\text { Thermal } \\
\text { Cond. } \\
\left(\mathrm{W} / \mathrm{cm}^{*} \mathrm{~K}\right)\end{array}$ \\
\hline 200 & 0.14246 \\
\hline 300 & 0.16658 \\
\hline 400 & 0.19134 \\
\hline 500 & 0.21676 \\
\hline 600 & 0.24283 \\
\hline 700 & 0.26955 \\
\hline 800 & 0.29693 \\
\hline 900 & 0.32496 \\
\hline 1000 & 0.35364 \\
\hline 1200 & 0.41297 \\
\hline
\end{tabular}

Specific
Heat:

$\mathrm{Cp}(\mathrm{T})=0.09307013+1.5615193 \mathrm{e}-4 * \mathrm{~T}-2.1177933 \mathrm{e}-7 * \mathrm{~T} * \mathrm{~T}+1.9364931 \mathrm{e}-10 * \mathrm{~T} * \mathrm{~T} * \mathrm{~T}$ where: $\mathrm{Cp}[=] \mathrm{J} / \mathrm{gm} * \mathrm{~K}$ $\mathrm{T}[=] \mathrm{K}$

$\begin{array}{cc}\begin{array}{c}\text { Temperature } \\ (\mathrm{K})\end{array} & \begin{array}{c}\text { Specific } \\ \text { Heat } \\ (\mathrm{J} / \mathrm{gm} * \mathrm{~K})\end{array} \\ & \\ 300 & 0.12608 \\ 350 & 0.13008 \\ 400 & 0.13404 \\ 450 & 0.13810 \\ 500 & 0.14241 \\ 550 & 0.14711 \\ 600 & 0.15235 \\ 650 & 0.15827 \\ 700 & 0.16503 \\ 750 & 0.17275 \\ 800 & 0.18160 \\ 850 & 0.19171\end{array}$




\section{Young's Modulus:}

$\begin{array}{cc}\mathrm{YM}(\mathrm{T})=(2.011658-2.0859896 \mathrm{e}-3 * \mathrm{~T}+3.5424944 \mathrm{e}-6 * \mathrm{~T} * \mathrm{~T}-2.7977181 \mathrm{e}-9 * \mathrm{~T} * \mathrm{~T} * \mathrm{~T}) * 1.0 \mathrm{e} 11 \\ \text { where: } \mathrm{T}[=] \mathrm{K} \\ \mathrm{YM}[=] \mathrm{Pa} \\ \text { Temperature } & \mathrm{YM} \\ (\mathrm{K}) & (\mathrm{Pa}) \\ & \\ 300 & 1.62915 \mathrm{E}+11 \\ 350 & 1.59557 \mathrm{E}+11 \\ 400 & 1.56501 \mathrm{E}+11 \\ 450 & 1.53538 \mathrm{E}+11 \\ 500 & 1.50457 \mathrm{E}+11 \\ 550 & 1.4705 \mathrm{E}+11 \\ 600 & 1.43106 \mathrm{E}+11 \\ 650 & 1.38415 \mathrm{E}+11 \\ 700 & 1.32767 \mathrm{E}+11 \\ 750 & 1.25953 \mathrm{E}+11 \\ 800 & 1.17763 \mathrm{E}+11 \\ 850 & 1.07987 \mathrm{E}+11\end{array}$

\section{Thermal Expansion:}

$\Delta \mathrm{L}(\mathrm{T}) / \mathrm{L} 293=\left(-0.424+1.658 \mathrm{e}-3 * \mathrm{~T}-1.052 \mathrm{e}-6 * \mathrm{~T}^{*} \mathrm{~T}+1.115 \mathrm{e}-9 * \mathrm{~T}^{*} \mathrm{~T} * \mathrm{~T}\right) / 100$ where: $\mathrm{T}[=] \mathrm{K}$

data range of $293<\mathrm{T}<900$

\section{Phase Change and Melting Points:}

$\mathrm{U}-10 \mathrm{Zr}$ phase transformation $(\delta$ to $\mathrm{U}[\gamma] \mathrm{Zr}[\beta])$ at $890 \mathrm{~K}$

$\mathrm{U}$ melting point at $1407 \mathrm{~K}$

$\mathrm{Zr}$ melting point at $2127 \mathrm{~K}$

$\mathrm{U}-10 \mathrm{Zr}$ solidus temperature at $\sim 1507 \mathrm{~K}$

Poisson's Ratio $=0.24$ 
APPENDIX $B$.

RESULTS 



\section{APPENDIX B. RESULTS}

Results from ABAQUS modeling: The commercial finite element code ABAQUS was used to simulate the test problem for the $\mathrm{U}-\mathrm{Zr}$ fuel. Due to the isotropic nature of the fuel behavior, 2-D axi-symmetric elements were used to discretize the fuel cross-section containing the radial and axial directions. The thermal and mechanical analyses were performed sequentially, with the temperature distribution from the thermal analysis forming an input to the subsequent mechanical analysis.

The thermal analysis was performed assuming the gap between the fuel pin and the clad to be filled with liquid sodium. Temperature dependent properties for the U-Zr fuel, HT-9 clad and liquid sodium (listed in Appendix 1) were used in the analysis. The heat transfer coefficient and coolant temperature at the outer surface of the clad (Appendix 1) were specified through a user subroutine to account for the non-uniform values that varied with axial position. In addition, the variation in the axial power distribution, which affects the heat generation, was also specified through a user subroutine. The thermal analysis was used to compute the temperature field in the fuel and clad under steady state operating conditions. Figure 1 shows the temperature variation with normalized height along the axial direction at the fuel center and fuel surface for case 2. The temperature difference between the center and surface is higher near the middle, where the axial power factors are the highest, compared to the top or bottom sections of the fuel rod.

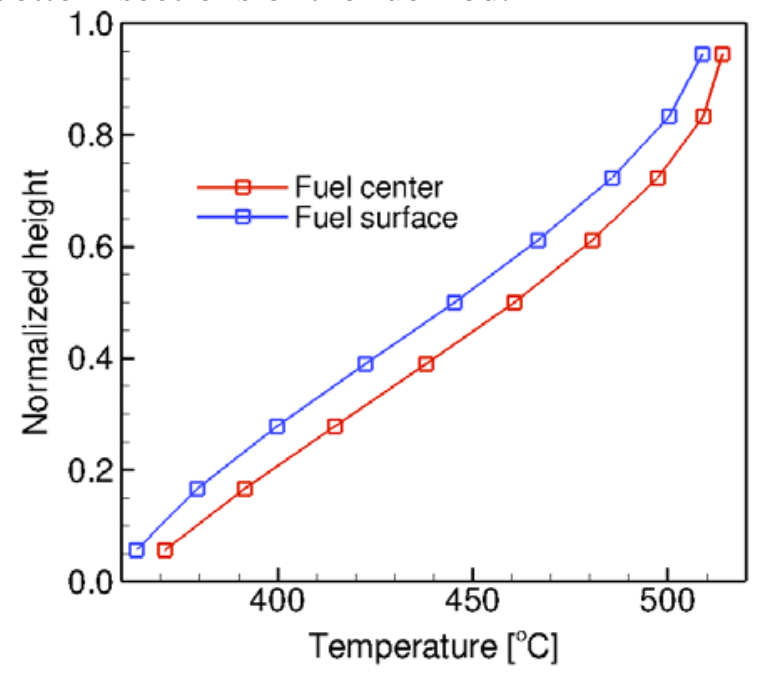

Figure 1: Temperature variation with normalized height along the axial direction at the center and surface of the fuel rod for case 2 .

The temperature field was used in the mechanical analysis to determine the volume change due to thermal expansion. For the mechanical analysis, the space between the fuel and the clad was treated as being empty. Fuel swelling was modeled by adding a term similar to thermal expansion in a user subroutine based on burnup, which was treated as a state variable. The burnup was assumed to increase at a constant rate with time, and the axial power factors were used to compute the total burnup at a given height. The overall expansion was therefore computed by adding the contributions from thermal expansion and fuel swelling (at a rate of $6 \%$ per at $\%$ burnup [1]). Figure 2 shows the time to close the gap between the fuel and the clad at different axial positions for case 2. Gap closure occurs earlier for positions near the center of the fuel, since the power factors here are the highest. 


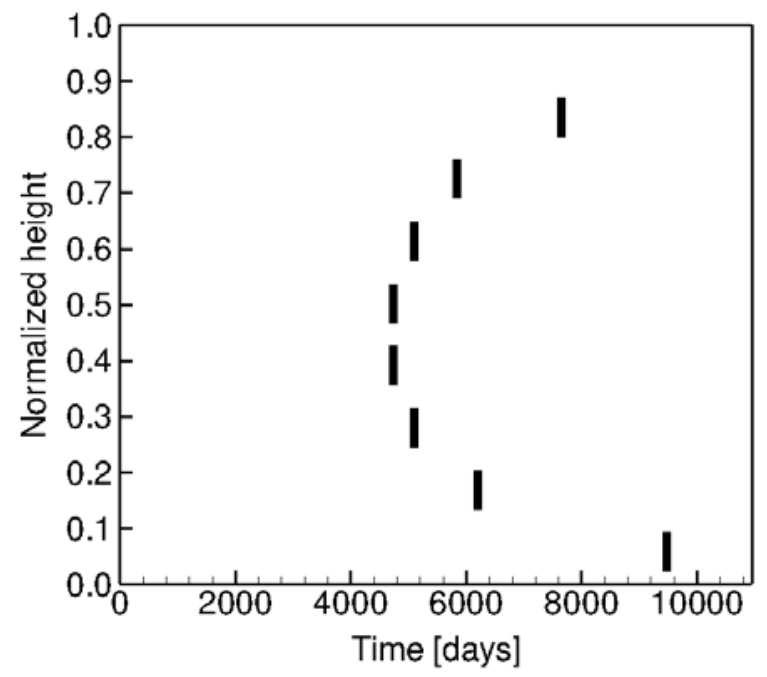

Figure 2: Time to close the gap between the fuel and the clad at different normalized heights, based on power factors for case 2 .

One the fuel rod makes contact with the clad, sticking friction condition was assumed between the contacting surfaces. It was also assumed that the clad material does not undergo any deformation and behaves as a rigid body [1]. Based on these assumptions, the free expansion of the fuel rod is constrained once it makes contact with the clad, with further expansion limited to the portion of the fuel rod above the closed gap.

Based on the axial power factors for the two cases given in ref. [1], the axial growth of the fuel rod was computed as a function of time, as shown in Figure 3. The initial portion of the curve with constant slope shows the axial growth before any contact with the clad. Gap closure occurs slightly earlier for case 1 compared to case 2 . Once the gap has closed, axial growth is limited to the section of the fuel above the closed gap, leading the slower axial growth. After 30 years of operation, case 1 leads to a slightly higher axial growth compared to case 2 .

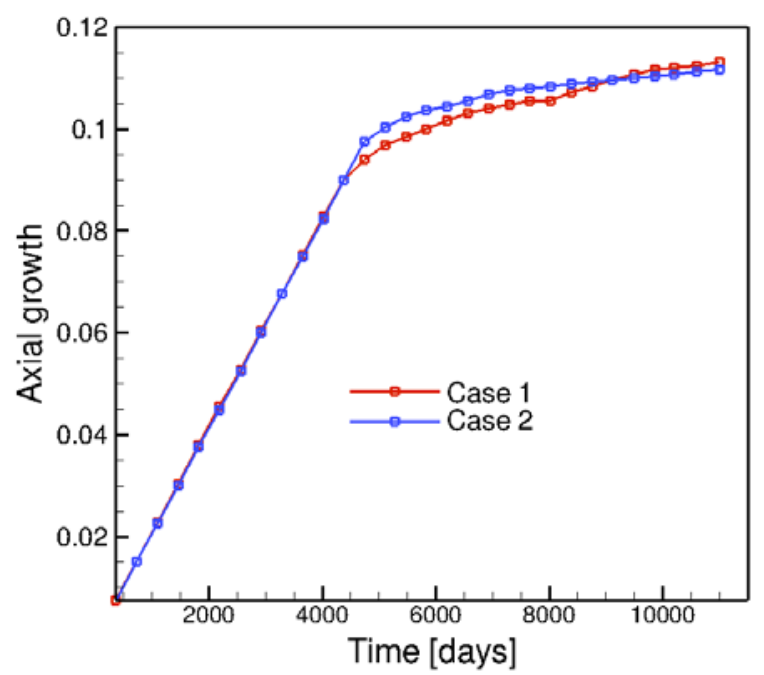

Figure 3: Axial growth relative to initial height of the fuel rod for the two cases with different power factors. The change is slope indicates initial contact with the clad. 
Results from ADVENTURE modeling: The temperature profile in the fuel slug shows the variation from surface to center and exhibits a good agreement between simulated and analytical values, as shown in Figure 4. Figure 5 shows the simulation of fuel swelling. The gap between the fuel (blue) and the clad (green) is filled with liquid sodium (red) that gets pushed up into the plenum as the fuel expands. Ultimately, the fuel-clad gap closes when all the sodium in the gap is pushed up. Figure 6 shows the simulated values for the time for complete closure of the fuel-pellet gap and the comparison with analytical values.

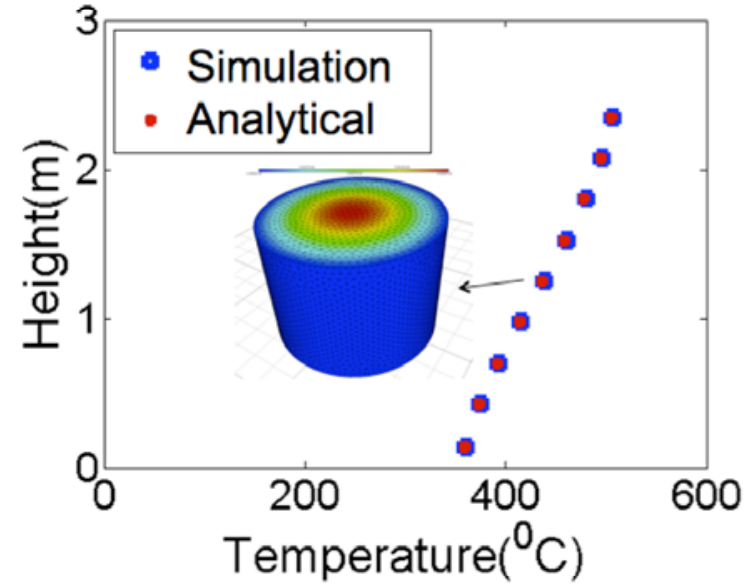

Figure 4. Simulation of fuel temperature

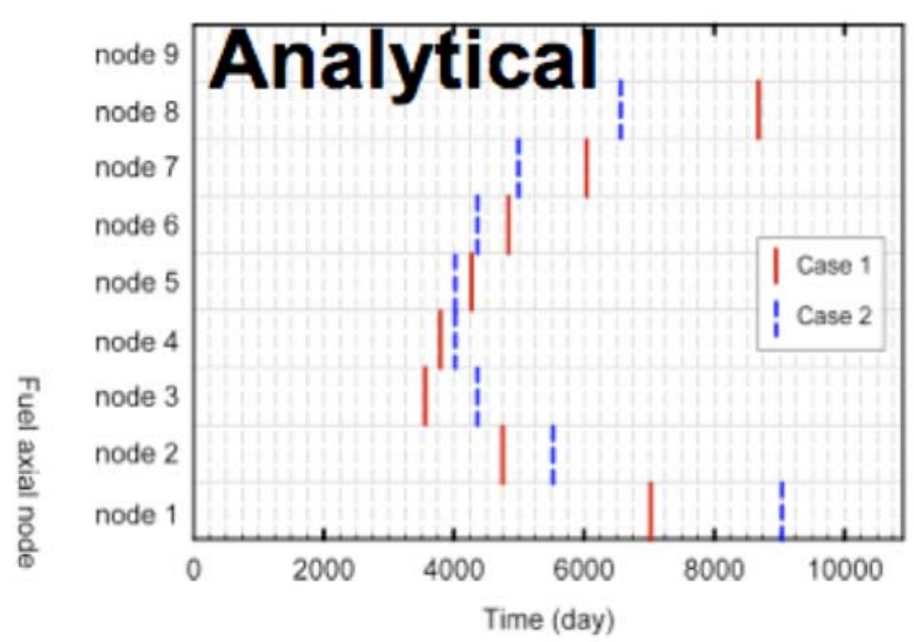

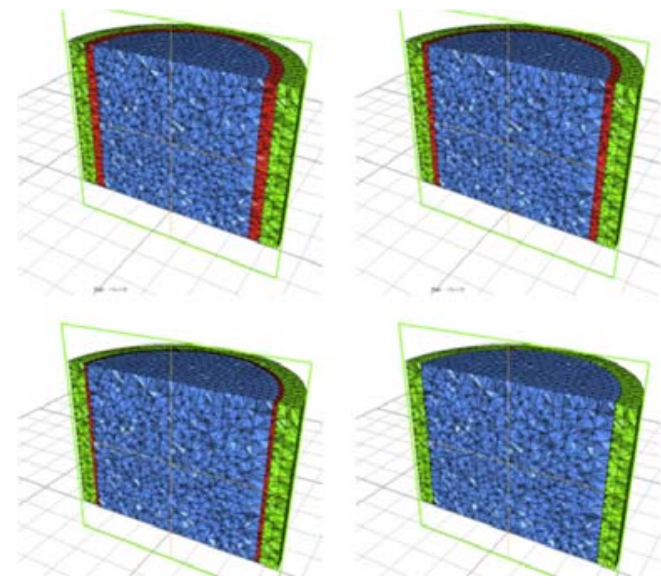

Figure 5. Simulation of fuel-clad gap closure

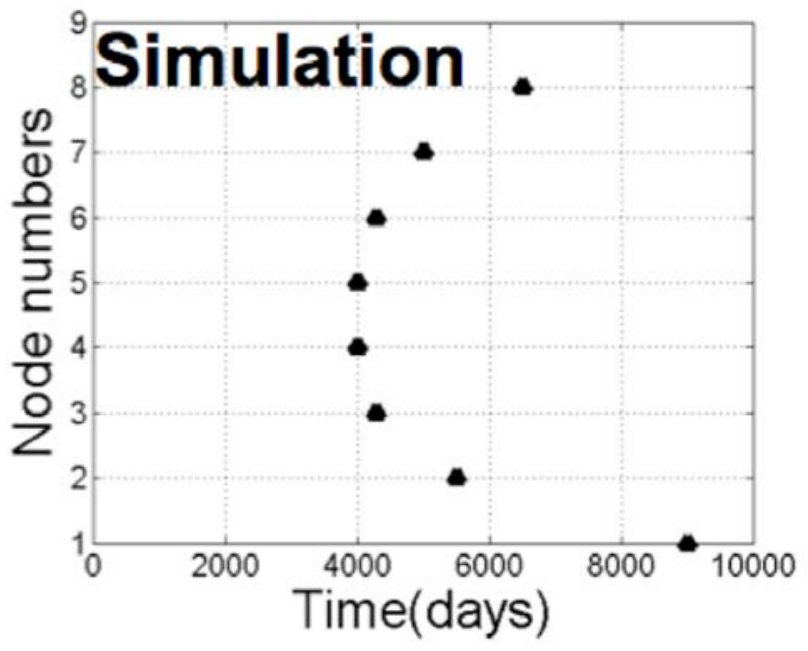

Figure 6. Time for gap closure showing analytical values (left) and simulated values (right) 
